\title{
РОЗВИТОК ІДЕЙ С. ДОРОШЕНКА ДЛЯ СТАНОВЛЕННЯ ГРАМАТИКИ ОЦІНКИ. ІНФІНІТИВ В АСПЕКТІ ЛІНГВОАКСІОЛОГІЇ
}

У статті проаналізовано особливості функціювання інфінітивних дієслівних форм 3 використанням ідей граматичної стилістики української мови С. Дорошенка (на матеріалі посібника «Граматична стилістика української мови»). Описано механізм моделювання граматичної ігреми для вираження оцінки з участю досліджуваних форм (модель «Сидіти!»).

Ключові слова: граматична стилістика, інфінітив, ігрема, оцінка, украӥнська мова.

Khaliman O. V. The Development of S. Doroshenko's Ideas for the Grammar of Estimation Formation. Infinitive in the Aspect of linguistic Axiology. The analysis of the functional features of grammatical units allows linguists to focus on their pragmatic significance in the communicative process. Grammatical units as the means of appreciation expressing require multipurpose research, which demands the continuation of the problem development and determines the actuality of the study. The aim of this research is to analyze the peculiarities of infinitive verbal forms functioning with using the ideas of the grammatical stylistics of the Ukrainian language by S. Doroshenko (on the material of the manual «Grammatical stylistics of the Ukrainian language» (Doroshenko, 1985)); to describe the mechanisms of grammatical ludism for the appreciation expressing with infinitive forms.

The article describes the process of grammatical ludism modeling (a unit that is formed by purposeful violations of grammatical norms, restrictions for achieving communicative-pragmatic goals) with the infinitive forms (the model «Cuдimu.»). Infinitive verbal forms which are used in the imperative meaning instead of personal forms, metaphorically, function as the means of negative expression. The definition of an action not according to the norms, but to the categorical demand of the subject indicates his/her dismissive, ignorant, negative attitude towards the addressee. The usage of such language means determines the connection between the semantics of politeness and the semantics of estimation which allows to model the corresponding pragmatic meaning in a peculiar way.

As such forms in the official language are typical in the documents and do not express the negative meaning, their usage can cause communicative deviations between the speaker and addressee through unequal perception of simulated pragmatic meanings. In particular the addressee may understand the motivation as negative through the appropriate experience of using the infinitive forms in the situation when the speaker does not want to express the specific estimation.

Key words: grammar stylistic, infinitive, ludism, estimation, Ukrainian language.

\section{Вступ}

У сучасній лінгвістиці, крім звичних академічних граматик, усе частіше натрапляємо на наукові описи на зразок «функційна граматика», «асоціативна граматика», «комунікативна граматика», «граматика мовця», «лексична граматика», «креативна граматика», «об’єктивна граматика» та ін. (Див. про це Норман, 2015: 91). Очевидно, пояснює Б. Норман, традиційна граматика й традиційний словник як «керівництво для мовленнєвих дій» не задовольняють носія мови, оскільки вони недостатньо відображають мовленнєву реальність (Норман, 2015: 91). Аналіз функційної специфіки граматичних одиниць дає змогу мовознавцям акцентувати увагу на їхній прагматичній значущості в 
комунікативному процесі. Згаданий учений наголошує, що в цих умовах «новий граматичний компендіум має являти собою інтегративний опис, свого роду інваріант щодо всіх можливих варіантів мовного існування» (Норман, 2016: 31).

Серед сучасних описів граматичних одиниць своє місце посідає граматика оцінки - опис арсеналу граматичних засобів вираження оцінних значень, що забезпечить формулювання правил уживання граматичних одиниць в оцінних функціях та трактування закономірностей їхнього адекватного тлумачення (Космеда \& Халіман, 2011). Співвідносячи структурні особливості одиниць із комунікативним процесом, граматика оцінки грунтується на лінгвістичному функціоналізмі, що є основою граматики активного типу.

Інформація про вираження оцінних значень окремими грамемами трапляється в дослідженнях зі стилістики та стилістичної морфології, серед них - наукова праця С. Дорошенка, якому, як зауважує Л. Лисиченко, «належать піонерські роботи з граматичної стилістики» (Лисиченко, 2018: 3). Аналізуючи стилістичні засоби морфології, С. Дорошенко аспектуально вказує на їхні особливості у фокусі лінгвоаксіології, тобто характеризує їх як засоби вираження оцінки. У посібнику з граматичної стилістики знаходимо твердження щодо можливостей вираження оцінних значень під час уживання таких одиниць:

- граматичних значень роду (подано аналіз уживання форм середнього роду іменників, прикметників, займенників (Дорошенко, 1985: 46-47);

- граматичних значень числа (описано функціювання числових форм, що в граматиці оцінки кваліфікуємо як узагальнювальна множинність (Дорошенко, 1985: 53), множина пошанна (Дорошенко, 1985: 88), удавана пошанність (Дорошенко, 1985: 54);

- граматичних значень особи (наведено коментарі щодо переносного вживання особових займенників та дієслівних форм (Дорошенко, 1985: 89));

- граматичних значень способу (проаналізовано синонімічні відношення між формами способів дієслів (Дорошенко, 1985: 101-102));

- інфінітивних форм (розглянуто функції інфінітива, окремі з яких стосуються вираження оцінки (Дорошенко, 1985: 13, 104)).

I до сьогодні знаходимо суперечливі погляди науковців щодо співвіднесення понять оцінка - емоційність - експресивність. С. Дорошенко звертає на це увагу й пояснює, що слово «емоційний має значення викликаний емоціями: той, що виявляє емоції, тобто проявляє душевні переживання, почуття гніву, печалі, радості» (Дорошенко 1985: 11-12). Кожна емоція є позитивною чи негативною, отже, має оцінний характер. Експресивний, наголошує дослідник, «слід розуміти як виразний, наділений експресією», експресивні мовні одиниці «посилюють вплив на думки й почуття читачів чи слухачів» (Дорошенко 1985: 12). Отже, емоційність не завжди експресивна, а експресія породжується не лише емоціями.

У попередніх публікаціях для опису граматики оцінки ми також використовували твердження С. Дорошенка щодо стилістичних засобів української граматики (Халіман, 2010: 169, 176). Мета розвідки - проаналізувати 
особливості функціювання інфінітивних дієслівних форм з використанням ідей граматичної стилістики української мови С. Дорошенка (на матеріалі посібника «Граматична стилістика української мови» (Дорошенко, 1985)); описати механізм моделювання граматичної ігреми для вираження оцінки 3 участю інфінітивних форм.

\section{Методи та методики дослідження}

У процесі дослідження було застосовано метод спостереження, описовий метод (прийоми внутрішньої й зовнішньої інтерпретації); метод моделювання покладено в основу дослідницького абстрагування для виявлення ознак фактичного матеріалу через його мисленнєве й формалізоване подання. Для дослідження оцінної семантики використано методи компонентного, контекстуального, порівняльного аналізів; методи вибірки - для відбору фактичного матеріалу.

\section{Результати та дискусії}

Щодо місця інфінітива серед інших дієслівних форм існують різні погляди. Одні дослідники, уважаючи інфінітив початковою, вихідною дієслівною формою, ставлять його на перше місце й розглядають як центр дієслівної системи. Друге місце вони відводять особовим формам, останні місця - дієприкметникові та дієприслівникові. Такої думки дотримувалися Д. Овсянико-Куликовський, О. Шахматов та лінгвісти бодуенівської школи, наголошуючи, що інфінітив - це «дієслівний номінатив», тобто основна, вихідна форма дієслова (Виноградов, 1972: 255). Інші основними вважають дієвідмінювані форми, а інфінітив ставлять на четверте місце після дієприкметника та дієприслівника (Русанівський, 1969: 297-298). У посібнику з граматичної стилістики С. Дорошенко зауважує, що стилістична особливість інфінітива полягає в його здатності виступати в ролі різних способів, набуваючи при цьому експресивно-смислових відтінків. Описуючи стилістичні функції інфінітива, названий вище дослідник наводить твердження, що свідчать про участь досліджуваних форм у механізмах породження аксіологічних відтінків значень.

Інфінітивні форми, що «є виразником директивного значення» (Вихованець \& Городенська, 2004: 262), уважають периферією імперативності. Вони реалізують мовленнєві акти наказу (з його варіантами - команди й розпорядження), вимоги й заборони, напр.: Відділення, покласти зброю! (зі статуту Збройних сил України); Негайно робити уроки! (розм.); За огорожу не заходити! (напис на щиті біля будівельного майданчика); Не палити! (напис на дверях приміщення інституту) (Нарушевич-Васильєва, 2002: 9).

Описуючи завдання занять 3 граматичної стилістики, С. Дорошенко доводить важливість уміння стилістично правильно оформляти думки, при цьому наводить приклади морфологічних синонімів, що мають різне стилістичне забарвлення й відзначаються сферою використання. Серед наведених прикладів - система форм на зразок сідай - сидіти - сядь-но, з яких саме інфінітив, як слушно наголошує дослідник, має відтінок категоричності (Дорошенко, 1985: 13). Цю думку підтверджують інші науковці у своїх 
розвідках. Наприклад, у посібниках зі стилістики теж знаходимо думки про те, що інфінітив у значенні наказового способу використовують для вираження особливої категоричності (Кожина, 2008 259; Стилістика української мови, 2017: 81). Спонукальні конструкції з незалежним інфінітивом, як зауважує О. Нарушевич-Васильєва, за своєю семантикою «відзначаються категоричністю, повинністю, необхідністю» (Нарушевич-Васильєва, 2002: 12). Це, на іiі думку, зумовлює часте використання їх мовцем, який має вищий соціальний статус у зіставленні з адресатом. Порівнюючи імперативні форми для пом'якшеного чи жорсткого впливу на адресата, Л. Богданова серед засобів, що дають змогу підкреслити «беззаперечність виконання вимоги», називає форми інфінітива, напр. (у перекл. укр.): Стояти! Не стрілятии! (Богданова, 2016: 180).

Крім цього, С. Дорошенко звернув увагу на сферу застосування досліджуваної моделі. Він наводить приклади газетних заголовків, тим самим аргументуючи, що неозначену форму дієслова «як заклик до здійснення необхідних заходів» використовують передусім у публіцистиці й наводить такі приклади: Пращювати ефективно і якісно; Виховувати надійних захисників Вiтчизни (Дорошенко, 1985: 104).

Це засвідчують дослідники в наукових роботах у XXI столітті, наприклад, як стверджує О. Нарушевич-Васильєва, актуалізовані конструкції «найчастіше вживаються й відзначаються структурно-семантичною різноманітністю в публіцистичному й розмовному стилях» (Нарушевич-Васильєва 2002: 13). У газетному мовленні, як зауважує М. Кожина, цю форму використовують у заголовках статей, напр. (у перекл. укр.): Зупинити руку вбивць! (Кожина, 2008: 259). Як відомо, заголовок, що дає первинну інформацію про текст, посідає сильну текстову позицію, тому тут важливо використовувати форми, найбільш виразні прагматично, зокрема й аксіологічно. Отже, сучасні наукові розвідки засвідчують уживання таких заголовків, хоча, як видається, у зв'язку з демократизацією суспільства вживання категоричних спонукань мало б зменшитися. Наприклад, таку думку висловлює Л. Брутян, зауважуючи, що значна кількість імперативних форм «відображає адміністративно-командну структуру суспільства» (Брутян, 2016: 75) й наводить саме приклади інфінітивних наказів.

Крім того, знаходимо досліджувану модель у мовленні персонажів, що виявляється в художньому стилі, напр.: - У вояків і ціпаків не стріляти! (Р. Іваничук); Вперед! I нікого не жсаліти! Палити і вбивати -- це наказую вам я, хан Кончак, син Атрака, внук великого Шарукана! (В. Малик); - Братіє, велю держатися всім купно! Із бойового ряду нікому не виїжджати! Вперед не зариватися $i$ ззаду не залишатися! Хто покаже ворогові хребет, тому ганьба на віки вічні! (В. Малик). Тут форму інфінітива вживають замість форм наказового способу «для посилення наказу», напр.: Разом з населенням рухатись далі на німецькі окопи. Жодного пострілу. Плакати, лозунги, музика" (О. Довженко) (Пономарів, 2000: 159).

У художньому й публіцистичному мовленні, наголошує І. Голуб, такі речення «вводять у діалоги й монологи, насичені емоціями» (Голуб, 2003: 
349), тобто тексти аксіологічно марковані. Як бачимо, речення відрізняються інтонаційним оформленням - більшість з них окличні. Завдяки такій інтонації, як зауважує дослідниця, «інфінітивні речення несуть величезний експресивний заряд і виділяються особливою напруженістю» (Голуб, 2003: 349).

В офіційно-діловому стилі такі моделі теж досить частотні, однак відрізняються структурно-семантичною одноманітністю. Синтаксис ділової документації «характеризується наявністю узвичаєно вживаних інфінітивних конструкцій у реченнях резолютивного змісту (у розпорядчій документації рекомендується вживати інфінітивні форми: затвердити, зобов'язати, відзначити, попередити та ін.)» (Стилістика української мови, 2003: 103). У науковій сфері їхнє використання обмежується навчальною літературою (Нарушевич-Васильєва, 2002: 13). Урізноманітненню вживань, як зауважує I. Голуб, перешкоджає їхнє експресивне забарвлення (Голуб, 2003: 349). У цих стилях імперативна форма інфінітива набуває відтінку офіційності, проте категоричності спонукання не виражає. Очевидно, саме таке їхнє вживання є нормою й не містить додаткових відтінків.

Усе-таки, як видається, описані вживання необхідно розмежувати. Справді, уживаючись для передачі імперативності, інфінітивна форма $є$ типовою для розпорядчої документації та навчальної літератури. У художньому, публіцистичному та розмовному стилях ії̈ використовують, як було зазначено, для посилення категоричності. Проте окремого аналізу потребує використання досліджуваної форми щодо однієї чи кількох осіб. У цьому разі інфінітивну форму вживають замість більш доречної особової форми наказового способу. Інфінітивна форма, на відміну від особових форм, (а) нівелює зв'язок названої дії з конкретною особою, (б) породжує конфлікт з позначуваними денотатами в тому разі, коли форму адресовано одній чи кільком особам і вимога не стосується широкого загалу. Про це пише й Л. Шевцова: «Об'єкт, якому адресовано наказ, відходить на задній план, а особливий акцент дається на безвідкладне виконання дії, часто з окличною інтонацією» (Шевцова, 2001: 57). Це сприяє деіндивідуалізації спонукання й граматичній метафоризації форми.

Основною особливістю спонукання у формі інфінітива, як бачимо, дослідники вважають вираження категоричності. Категоричність, як пояснює К. Бортун, - форма висловлення, яка дає партнерові змогу зрозуміти, що мовець уважає свою думку істиною в останній інстанції. Категоричність «відображає зневагу до думки партнера, ії свідоме несприйняття» (Бортун, 2016: 15). Вияв категоричності пов'язаний з вибором мовленнєвих тактик погрози, докору, попередження, ультиматуму, різкої оцінки, що, на думку мовця, примусять співрозмовника виконати вимогу (Бортун, 2016: 15).

Спонукання, безперечно, семантично неоднорідна категорія. Зокрема, деякі мовні одиниці виражають спонукання в поєднанні з повинністю (Русская грамматика, 1982: 114). Це модальне значення, що передає «приписи дії, зумовленої законами, звичаями, традиціями, правилами етикету, особистим досвідом мовця, звичайним проходженням подій, тобто нормам 
у широкому сенсі цього слова» (Осетров, 1984: 84). Т. Чумакова звертає увагу на таку закономірність: що більш категоричне спонукання, то слабший відтінок повинності й навпаки (Чумакова, 2013: 119). Коли повинність виступає на перший план, некатегоричне спонукання з неокличною, спокійною інтонацією має характер нагадування, пропозиції. Вимога, наказ, навпаки, можуть повністю нейтралізувати смислове вираження повинності.

Інфінітив, як було зазначено, слугує для вираження більш категоричних вимог, заборон наказів: «інфінітивне речення вибирає такий мовець, який вищий, ніж адресат за соціальним статусом, за яким закріплене адміністративне, юридичне чи моральне право розпоряджатися» (Чумакова, 2013: $120)$, або ж мовець таким себе вважає. Недоречна категоричність породжує з'яву додаткових відтінків значення, коли виконання дії зумовлене не нормою, усвідомленою суб'єктом дії, а її обов'язковий характер визначено волею іншої особи.

Категорія категоричності, як зазначає К. Бортун, співвідноситься 3 вираженням увічливості (Бортун, 2016: 15). Досліджувана модель, характеризуючись категоричністю, під час заміни більш доречних особових форм увічливістю не відзначається. Метою неввічливої поведінки, як пояснює В. Карасик, «може бути прагнення вийти на відкритий конфлікт і з'ясувати стосунки з партнером на персональній дистанції, бажання принизити партнера по спілкуванню й змінити статусне ставлення на соціальній дистанції» (Карасик, 1992). Увічливість - це насамперед спосіб вираження поваги до іншої людини. Повага як категорія, що вербалізує й оцінку, належить до градуальних величин і «варіює від максимальної поваги, поклоніння, до нульової позначки (відсутність поваги) й далі - до неповаги, зневаги» (Карасик, 1992), тому репрезентація ввічливості, як зазначає Т. Федорова, «супроводжується вираженням різних емоційно-оцінних конотацій, що свідчить також про зв'язок семантики ввічливості із семантикою оцінки» (Федорова, 2004: 18).

Застосування мовних одиниць, що відзначаються надмірною категоричністю й, відповідно, неввічливістю, передбачає вираження негативу мовця до адресата. Тобто негативну оцінку можна висловити засобами недоречної категоричності, неввічливості, оскільки «оцінка може торкатися не тільки параметрів добре / погано, правда / неправда, але й доречності й недоречності висловлювання, тобто принципів співробітництва й ввічливості» (Оцінка і комунікація, 2013: 59).

Як демонструє досліджуваний матеріал, в офіційно-діловому й науковому стилях, де відсутня необхідність індивідуалізації, інфінітивні речення є нормою для вираження спонукання, оскільки воно не адресоване конкретній особі, тим самим забезпечує узагальненість вимоги, її сухість, офіційність. У художньому, публіцистичному та розмовному стилях така модель може виражати негатив, особливо в тому разі, коли вживається замість особової форми наказового способу. Ігнорування конкретної особи, якій адресовано вимогу, сприймається як її деіндивідуалізація, ототожнення / узагальнення з іншими, що забезпечує сприйняття наказу як негативного ставлення. 
У художньому стилі спостерігаємо використання досліджуваних одиниць у мовленні негативних персонажів, зокрема вони поширені в текстах, сюжети яких відтворюють опис воєнних, революційних подій, що пов'язано з реалізацією протиставлень свій / чужий, напр.: - Ану встать! - випростався поліцай. Два інші тежк похмуро дивилися на шевия. - Вста-ать. Кому сказано!!! (Григір Тютюнник). У такий спосіб «чужі» виражають негативне ставлення до «своїх». Крім того, досліджуваний мовний засіб можна вважати ознакою мовлення певного типу персонажів.

\section{Висновки}

Отже, успішність комунікації пов'язана з умілим застосуванням способів впливу на співрозмовника. Інфінітивні дієслівні форми, використані в імперативному значенні замість особових форм, метафоризуючись, функціюють як засоби вираження негативу. Зумовленість дії не нормами, а категоричною вимогою суб'єкта демонструє його зневажливе, неввічливе, негативне ставлення до адресата. Уживання досліджуваного мовного засобу засвідчує зв'язок семантики категоричності, семантики ввічливості із семантикою оцінки, що дає змогу моделювати відповідні прагматичні смисли.

Оскільки такі форми в офіційному мовленні є типовими в розпорядчій документації й негативу не виражають, їх використання може створювати непорозуміння в комунікації, спричиняти комунікативні девіації через неоднозначне сприйняття змодельованих прагматичних смислів мовцем й адресатом, зокрема адресат може сприйняти спонукання як негатив через відповідний досвід уживання інфінітивних форм. Для успішного спілкування комунікативні інтенції й, відповідно, значення використаних мовних засобів мають однаково сприймати й трактувати обидва учасники.

У перспективі плануємо аналіз інших граматичних одиниць української мови у виокремленому ракурсі для створення цілісної теорії граматики оцінки.

\section{ЛІТЕРАТУРА}

1. Богданова Л. И. Шкала императивности в русском языке Сборник тезисов Международного научного симпозиума «Русская грамматика 4.0» (Москва, 13-15 апреля 2016 года). Москва, 2016. С. 178-180. 2. Бортун К. О. Імперативність і категоричність у структурі висловлення Науковий вісник Міжнародного гуманітарного університету. Серія «Філологія». 2016. № 20. Т. 1. С. 14-16. 3. Брутян Л. Г. От грамматики русского языка к русской языковой личности Сборник тезисов Международного научного симпозиума «Русская грамматика 4.0» (Москва, 13-15 апреля 2016 года). Москва, 2016. С. 72-77. 4. Виноградов В. В. Русский язык: Грамматическое учение о слове. Москва, 1972. 606 с. 5. Вихованець І., Городенська К. Теоретична морфологія української мови: Академ. граматика укр. мови. Київ, 2004. 400 с. 6. Голуб И. Б. Стилистика русского язика. Москва, 2003. 448 с. 7. Дорошенко С. І. Граматична стилістика української мови. Київ, 1985. 200 с. 8. Карасик В. И. Язык социального статуса человека. Москва, 1992. 330 с. 9. Кожина М. Н., Дускаева Л. Р., Салимовский В. А. Стилистика русского языка: учебник. 4-е изд., стереотип. Москва, 2008. 464 с. 10. Космеда Т. А., Халіман О. В. «Граматика оцінки» як актуальна проблема сучасного мовознавства Лінгвістичні студіï. Донецьк, 2011. Вип. 22. С. 36-40. 11. Лисиченко Л. А. Пам’яті професора 
Сергія Івановича Дорошенка Лінгвістичні дослідження. 2018. Вип. 49. С. 3-4. 12. Нарушевич-Васильєва О. В. Категорія спонукальності у прагматичному аспекті : автореф. дис. ... канд. філол. наук. Одеса, 200220 с. 13. Норман Б. Ю. Грамматика каноническая, реальная и потенциальная Jezyk $i$ metoda: publikacja dofinansowana przez Uniwersytet Jagielloński ze środków Wydziału Filologicznego / red. D. Szumska. Kraków, 2015. С. 91-104. 14. Норман Б. Ю. Какая новая русская грамматика нам нужна? Сборник тезисов Международного научного симпозиума «Русская грамматика 4.0» (Москва, 13-15 апреля 2016 года). Москва, 2016. С. 30-32. 15. Осетров И. Г. Структурные разновидности простого предложения с модальным значением долженствования: дисс. ... канд. филол. наук: 10.02.01. Москва, 1984. 198 с. 16. Оцінка і комунікація : посіб. для студентів і аспірантів / укл. Г. І. Приходько. Вінниця, 2013. 168 с. 17. Пономарів О. Д. Стилістика сучасної української мови: підручник. 3-тє вид., перероб. і доповн. Тернопіль, 2000. 248 с. 18. Русская граматика: в 2 т. /под. ред. Н. Б. Шведовой. Москва, 1982. Т. 2.: Синтаксис. 720 с. 19. Стилістика української мови: навчально-методичний посібник /упорядники: А. С. Попович, Л. М. Марчук; за ред. А. С. Попович. Кам'янецьПодільський, 2017. 172 с. 20. Федорова Т. В. Семантика вежливости и средства ее выражения : автореф. дисс. ... канд. филол. наук. 10.02.01. Калининград, 2004. 18 с. 21. Халіман О. В. Морфологічні засоби вираження оцінки в сучасній українській мові: рід і число : дис. ... канд. філ. наук: 10.02.01. Харків, 2010. 280 с. 22. Чумакова Т. В. Синонимия инфинитивных предложений с модальной семантикой долженствования Вестник Южсно-Уральского профессионального института. 2013. 3 (12). С. 114-123. 23. Шевцова Л. С. Інфінітивні речення та їх синонімічні паралелі Украӥністика на порозі нового століття і тисячоліття. Оломоуць, 2001. С. 56-59.

\section{REFERENCES}

1. Bogdanova, L. I. (2016). Shkala imperativnosti v russkom yazyke [The scale of imperative in the Russian language]. Sbornik tezisov Mezhdunarodnogo nauchnogo simpoziuma «Russkaya grammatika 4.0» - Abstracts of the International Scientific Symposium «Russian Grammar 4.0». (pp. 178-180). Moskva: FGBOU VO «Gos. IRYa im. A.S. Pushkina» [in Russian]. 2. Bortun, K. O. (2016). Imperatyvnist i katehorychnist u strukturi vyslovlennia [Imperative and categorical in the structure of the statement]. Naukovyi visnyk Mizhnarodnoho humanitarnoho universytetu. Seriia "Filolohiia» - Scientific Herald of the International Humanitarian University. Series "Philology», 20, 14-16 [in Ukrainian]. 3. Brutyan, L. G. (2016) Ot grammatiki russkogo yazyka k russkoj yazykovoj lichnosti [From the grammar of the Russian language to the Russian language personality] Sbornik tezisov Mezhdunarodnogo nauchnogo simpoziuma «Russkaya grammatika 4.0» - Abstracts of the International Scientific Symposium «Russian Grammar 4.0». (pp. 72-77). Moskva: FGBOU VO «Gos. IRYa im. A.S. Pushkina» [in Russian]. 4. Vinogradov, V. V. (1972). Russkij yazyk: Grammaticheskoe uchenie o slove [Russian language: The grammatical doctrine of the word]. Moskva: Vyssh. shk. [in Russian]. 5. Vykhovanets, I. \& Horodenska, K. (2004). Teoretychna morfolohiia ukrainskoi movy: Akadem. hramatyka ukr. movy [Theoretical morphology of the Ukrainian language. Academic grammar of the Ukrainian language]. Kyiv: Univ. vyd-vo «Pulsary» [in Ukrainian]. 6. Golub, I. B. (2003). Stilistika russkogo yazyka [Stylistics of the Russian language]. Moscow: Ajris-press [in Russian]. 7. Doroshenko, S. I. (1985). Hramatychna stylistyka ukrainskoi movy [Grammatical stylistics of the Ukrainian language]. Kyiv : Rad. shk. [in Ukrainian]. 8. Karasik, V. I. (1992). Yazyk social'nogo statusa cheloveka [Human social status language]. Moskva: IYa RAN [in Russian]. 9 Kozhina, M. N., Duskaeva, L. R. \& Salimovskij, V. A. (2008). Stilistika russkogo yazyka [Stylistics of the Russian language]. (4nd ed.). Moskva: Flinta : Nauka [in Russian]. 10. Kosmeda, T. A. \& Khaliman O. V. (2011). «Hramatyka otsinky» yak aktualna problema suchasnoho movoznavstva [ "Grammar 
of estimation» as an actual problem of modern linguistics]. Linhvistychni studii - Linguistic studios. (Vols. 22). (pp. 36-40). Donetsk: DonNU [in Ukrainian]. 11. Lysychenko, L. A. (2018). Pamiati profesora Serhiia Ivanovycha Doroshenka [In memory of Professor Sergei Ivanovich Doroshenko]. Linhvistychni doslidzhennia - Linguistic research. (Vols. 49). (pp. 3-4). Kharkiv: KhNPU im. H. S. Skovorody [in Ukrainian]. 12. Narushevych-Vasylieva, O. V. (2002). Katehoriia sponukalnosti u prahmatychnomu aspekti [Category of incentive in the pragmatic aspect]. Extended abstract of candidate's thesis. Odesa: ONU im. I. I. Mechnykova [in Ukrainian]. 13. Norman, B. Yu. (2015) Grammatika kanonicheskaya, real'naya i potencial'naya [Canonical grammar, real and potential]. Język i metoda. (pp. 91-104). Kraków [in Russian]. 14. Norman, B. Yu. (2016) Kakaya novaya russkaya grammatika nam nuzhna? [What new Russian grammar do we need?]. Sbornik tezisov Mezhdunarodnogo nauchnogo simpoziuma «Russkaya grammatika 4.0» - Abstracts of the International Scientific Symposium «Russian Grammar 4.0». (pp. 30-32). Moskva: FGBOU VO «Gos. IRYa im. A.S. Pushkina» [in Russian]. 15. Osetrov, I. G. (1984). Strukturnye raznovidnosti prostogo predlozheniya s modal'nym znacheniem dolzhenstvovaniya [Structural variations of a simple sentence with a modal value of due].Candidate's thesis. Moskva: MPU im. N. K. Krupskoj. [in Russian]. 16. Prykhodko, H. I. (Eds.) (2013). Otsinka i komunikatsiia [Estimation and communication].Vinnytsia: Nova Knyha [in Ukrainian]. 17. Ponomariv, O. D. (2000). Stylistyka suchasnoi ukrainskoi movy [Stylistics of the modern Ukrainian language]. (3nd ed., rev.). Ternopil: Navchalna knyha-Bohdan [in Ukrainian]. 18. Shvedova, N. B. (Eds.) (1982). Russkaya gramatika [Russian grammar]. V 2 t. T. 2.: Sintaksis. Moskva: Nauka [in Russian]. 19. Popovych, A. S. (2017). Stylistyka ukrainskoi movy [Stylistics of the Ukrainian language]. Kamianets-Podilskyi: Kamianets-Podilskyi natsionalnyi universytet imeni Ivana Ohiienka [in Ukrainian]. 20. Fedorova, T. V. (2004). Semantika vezhlivosti i sredstva ee vyrazheniya [Semantics of courtesy and means of its expression]. Extended abstract of candidate's thesis. Bryansk: BGU [in Russian]. 21. Khaliman, O. V. (2010). Morfolohichni zasoby vyrazhennia otsinky v suchasnii ukrainskii movi: rid i chyslo [Morphological means of expressing an estimation in modern Ukrainian language: genus and number]. Candidate's thesis.. Kharkiv: KhNPU im. H. S. Skovorody, 2010. 280 c. 22. Chumakova, T. V. (2013) Sinonimiya infinitivnyx predlozhenij s modal'noj semantikoj dolzhenstvovaniya [Synonymy of infinitive sentences with modal semantics of obligation]. Vestnik Yuzhno-Ural'skogo professional'nogo instituta - Bulletin of the South Ural Professional Institute, 3 (12), 114-123. 23. Shevtsova, L. S. (2001) Infinityvni rechennia ta yikh synonimichni paraleli [Infinitive sentences and their synonymous parallels]. Ukrainistyka na porozi novoho stolittia i tysiacholittia - Ukrainianistic on the threshold of the new century and millennium. (pp. 56-59). Olomouts [in Ukrainian].

Халіман Оксана Володимирівна - кандидат філологічних наук, докторант кафедри української мови, Харківський національний педагогічний університет імені Г. С. Сковороди; вул. Валентинівська, 2, Харків, 61168, Україна.

Tel.: +38-066-55-903-66

E-mail: khaliman_oksana@ukr.net

https://orcid.org/0000-0001-6952-0627

Khaliman Oksana Volodymyrivna - PhD in Philology, Doctoral Student, Ukrainian Language Department, H.S. Skovoroda Kharkiv National Pedagogical University; Valentynivska Str., 2, Kharkiv, 61168, Ukraine.

Надійшла до редакції 25 лютого 2019 року 